DOI: https://doi.org/10.34069/AI/2021.38.02.12

\title{
Frame analysis as one of the effective methods of newspaper discourse studying
}

\section{Фреймовий аналіз як один з методів дослідження газетного дискурсу}

Received: March 2, 2021

Abstract

This paper outlines the study of the USA newspaper discourse from psycholinguistic perspectives. The research aims to thoroughly investigate the profound priorities, inconspicuous intentions of leading American mass media. The frame analysis has been used in our research. It is based on the cognitive theories of the representation of the speaker's knowledge, which retain verbal representation in speech, that is, frames. The main task of this analysis is to determine the leading categories, expressed by frame structures, which include slots containing the main ideas that the author wants to present to his audience. The research went through some stages which aimed at working on the most essential categories in the three articles and filling all the categories with the appropriate slots. The study revealed that most of the articles had three substantial categories which made it
Accepted: April 3, 2021

Written by:

Nataliia Diachuk ${ }^{31}$

https://orcid.org/0000-0002-5905-6813

Web of Science ResearcherID M-3649-2016

Tetiana Svyrydiuk ${ }^{32}$

https://orcid.org/0000-0001-9482-8228

Web of Science ResearcherID AAH-2825-2021

Tetiana Kryvoruchko ${ }^{33}$

https://orcid.org/0000-0001-7473-518X

Web of Science ResearcherID M-3644-2016

Inna Biliuk ${ }^{34}$

https://orcid.org/0000-0002-7409-6100

Web of Science ResearcherID AAR-2030-2020

Olha Levchenko ${ }^{35}$

https://orcid.org/0000-0002-9372-909X

Web of Science ResearcherID AAR-1037-2020

\footnotetext{
${ }^{31} \mathrm{PhD}$ (Psychology), Associate Professor, Educational and Research Institute of Foreign Philology of Zhytomyr Ivan Franko State University, Zhytomyr, Ukraine.

$32 \mathrm{PhD}$ (Philological Sciences), Assistant Professor, Department of Foreign Languages of the Faculty of Economics of Taras Shevchenko National University of Kyiv, Kyiv, Ukraine.

${ }^{33} \mathrm{PhD}$ (Philological Sciences), Associate Professor, Educational and Research Institute of Foreign Philology of Zhytomyr Ivan Franko State University, Zhytomyr, Ukraine.

${ }^{34} \mathrm{PhD}$ (Philological Sciences), Lecturer, Educational and Research Institute of Foreign Philology of Zhytomyr Ivan Franko State University, Zhytomyr, Ukraine.

${ }^{35} \mathrm{MA}$, Instructor, Educational and Research Institute of Foreign Philology of Zhytomyr Ivan Franko State University, Zhytomyr, Ukraine.
} 
possible to fully analyze the authors' intentions. The slot surveillance that makes the category vigilance very prominent is the paramount idea found in all the articles under discussion. It is realized via facial recognition technology and artificial intelligence. Among other vital categories are technological advances, protection, confidentiality, social interaction, credit system, personal data. All these categories have one thing in common as they are used as means for China people surveillance.

Key Words: newspaper discourse, frame analysis, slot, surveillance, protection.

\section{Introduction}

Nowadays mass media is not only the method for providing the information but a powerful tool to influence on people masses as well. That's why the interest to the concept of newspaper discourse is grabbing the attention of lots of scholars. Identification and analysis of certain patterns, regularities and dependencies of leading American media are vitally important. This will reveal the hidden purpose, true intentions and the main idea of the information provided, which is in its turn will allow us to get point of better understanding the peculiarities of the United States attitude via the given issue. The subject matter of the study is the USA newspaper discourse.

The topicality of our research is viewed via psycholinguistic approach of the study of the newspaper discourse. Known as a hybrid science, psycholinguistics aims to combine different methods and techniques to capture the attention of different population layers. Touching upon psychological aspects of person's comprehension and perceiving the information psycholinguistic method, frame analysis in particular, works on spreading the information among people of different background. Frame analysis helps to indicate true intentions of the media professionals in terms of seeking profit or desire to promote certain ideas. Frames guide the consumers' perception of each piece of information. Admittedly, the frame of each article is not always easy to detect and misinterpretations are a common risk, thus, it is extremely important to conduct further studies to the framing of news.

Technological progress leads to new challenges for human rights, since legal regulation applies to проаналізувати наміри авторів. Слот «відеоспостереження», що робить категорію «пильність» досить важливою обговорюється у всіх статтях, представлених для аналізу. Даний слот вивчається за допомогою технології розпізнавання обличчя та штучного інтелекту. Серед інших життєво важливих категорій технологічний прогрес, захист, конфіденційність, соціальна взаємодія, кредитна система, особисті дані. Усі ці категорії об'єднує те, що вони використовуються як засоби спостереження за жителями Китаю.

Ключові слова: газетний дискурс, фреймовий аналіз, слот, відеоспостереження, захист.

existing relationships and is not designed for the emergence of new forms. A striking example of this is the rapid introduction of integrated video surveillance systems, which can be used to monitor public order, crime detection, etc.

China is known to be a world leader in face recognition technology and regularly reminds its citizens that it is almost impossible to hide from the authorities with such equipment.

The country is building what is called "the world's largest camera surveillance network." About 170 million CCTV cameras have already been installed and about another 400 million new ones are planned to be installed over the next three years. Many cameras use artificial intelligence, including face recognition technology which has already become the influential technology marvel created by a human.

Hence, the article outlines the findings made by means of a thorough psycholinguistic analysis of the articles about the Chinese surveillance systems as a significantly important way to control the public order in China.

\section{Theoretical Framework or Literature Review}

As the media coverage is found to be extremely broad, different approaches, views, aspects have become the subjects for careful investigations by academicians and scientists. Nowadays a lot of papers and articles are devoted to the nature of media scope of important social issues in particular. For deeper understanding some speech facts it is appropriate and necessary to go beyond the linguistic study itself and 
interpenetrate the sphere of such psychological processes of the individual by which speech material is organized in the human brain and comes out at one moment.

Nowadays one of the most relevant areas of cognitive linguistics is frame analysis of the text. Frame analysis is directly related to the picture of the world. An individual's picture of the world is related to the pictures of the world in the minds of other people in many ways: scientific, religious, artistic. They include the concept of personality about society, freedom, good and evil, the system of values, etc. The artistic picture of the world is "the system of semantic, aesthetic, and emotional mixtures" in the human consciousness at the linguistic and phonetic levels and that is inherently artistic concepts (Diachuk, 2016).

Perception and understanding of any text are considered as two sides of the same phenomenon: procedural and productive. The process of text perception and text understanding is very complex touching upon at the lowest sensory level and ending at the highest semantic one. Reading the text the recipient does not have the task of understanding individual words or expressions. The comprehension process begins with the general content of the message, the hypothesis and only then moves to the lower levels, such as sensory (sound recognition), lexical (reproduction of individual words) and syntactic (perception of the content of individual sentences).

The comprehension process can be roughly divided into two logical stages: superficial comprehension - extraction of explicit information from messages provided by a language structure, and deep understanding extraction of implicit information that is expressed only when speech information is imposed on other information structures psychological, social, normative, moral and aesthetic (Dijk, 2008).

The reason of the difference in the perception of the same text lies in the emotional state at the moment of perception of the information and the individual's scheme of knowledge. The content is most adequately interpreted by the individual whose psychological structure of consciousness is as close as possible to the psychological features of the author's personality (Berger, 2019; Dijk, 2011).

The most obvious reaction whilst reading a text is the appearance of certain ideas, images or phenomena of the world in the reader's mind. These ideas are definitely related to the model of the world of the native speaker. A set of ideas that the addressee creates in the process of reading the text affects the way of designing and expanding the text, motivates the use of certain techniques of presentation. In this case, the linguistic mechanisms of the transmission of pragmatic information come to the fore. They aim not only to focus attention on any details, but affect the thoughts and emotional state of the addressee by the type of text, its content and the author's attitude (Fillmore \& Baker, 2012).

Language perception includes three aspects: the perception of speech signals itself, intellectual perception, that means the perception of expressed thought, and social understanding, that is, the perception of directly and indirectly expressed information about the social relations between the language user and the addressee, as well as between them and other social objects.

In order the addressee can perform the action programmed by the language user successfully, he must have information about the initial state of the world in which he is operating. It can be information about the current state of affairs, personal desires and opportunities, the wishes of others, as well as the rules and regulations managing his actions at the moment. Being involved in the communicative and pragmatic context of the text, communicators turn not only to knowledge of the language, norms and rules of its functioning. They also refer to their experience, information about the content of the text, strategies and procedures for obtaining the experience and knowledge representation (Ziem, 2014).

In the process of studying the mechanisms of text perception in applied linguistics it was pointed out that to recognize and record the content of text, it was necessary to build special linguistic frames, focused not so much on specific situations or objects, but on the texts which describe them (Leeper \& Slothuus, 2019).

A considerable amount of research has been carried out in the last few decades aiming to study and explain the concept "frame" (Baker \& Fillmore, 2012; Dijk, 2008; Nikonova, 2008; Schiffrin, Tannen \& Hamilton, 2015; Sonnet, 2019). Among other researchers who were keen on to investigate and make it clear how frame analysis works are M. Allen (2017), D. Kahneman (2013), J. A. Kuypers (2010), J. Stoughton (2017), L. Zasiekina (2007) and others. The newspaper texts from The 
Washington Post and The New York Times have brought the principal ideas for the analysis. Hence, psycholinguistics, sociolinguistic, comparative linguistics etc. are deeply rooted in the newspaper nature (Cacciatore \& Iyengar, 2016; Dobrosklonskaja, 2008; Hansen \& Machin, 2019; Knusden, 2014; Scheufele \& Tewksbury, 2007). Newspaper discourse has become a paramount issue not only for linguistics but for some hybrid branches of it. This is explained by the lexical changes in its structure and its influence upon the addressee. Newspaper articles are known as one of the most beneficial sources of obtaining and acquiring world's information. They serve a purpose to notify the audience of current news and issues of different significance. Due to widespread quick and easy open Internet access, almost all press reports and coverage are available in the online version. It enables to combine the effectiveness and visuality of television, as well as the ability to read the article over time. Newspaper discourse is seen as an independent kind of discourse that has specific features and performs certain functions. Modern American newspaper discourse is characterized by a tendency to express the author's point of view and selfexpression, on the one hand, and by an attempt to describe events objectively, on the other. Frame analysis made it possible to study the principal features of media coverage of tracking people in China.

\section{Methodology}

Frame analysis has always been beneficial for studying the communication studies, social movements, politics and news. This research method is regarded as one of the dominant techniques for investigating newspaper discourse as it mainly is used to analyse how people understand, perceive, comprehend situations and communication. (Zasiekina \& Zasiekin, 2008). Frame is known as a set of standard real or potential knowledge devoted to the complex phenomena, entire idea of complex concept. In other words, framing is an active system of knowledge statistics to speak for stereotyped sets of pictures. A frame is also viewed as a chain of representative knots and relations. The top levels of a frame are arranged to mean real and true things concerning the hypothesized situations. The lower levels contain many boundaries, called slots that must store definite details about the objects or data about them (Diachuk, 2017, pp. 40-46). A frame specifies the relationship between several connected elements in the text. Specifying this relationship can lead to full understanding of the problem nature highlighted in the text (Gorp, 2007, pp. 60-78).

The frame analysis of the research went through the following stages. In the first stage all the lexical units expressed by nouns have been noted. In the second stage all matching words have been grouped into specific categories. In the next stage the amount of lexical content of each group has been analysed. After that, the coefficient of prototype agent frequency and ratio of each category has been evaluated. In the last stage, the notions reflecting content development regarding the pattern Pre-Event Event - Post-Event among key items have been chosen (Zasiekina \& Zasiekin, 2008). For presenting the data of the analysis Microsoft Word was used.

\section{Results and Discussion}

To organize the empirical research all the matching words of all newspaper articles were grouped into specific categories. The first article "Beijing Bets on Facial Recognition in a Big Drive for Total Surveillance" that was subjected to the study is taken from the daily American newspaper "The Washington Post" (Denyer, 2018). Data analysis shows that the discourse of the article is mostly focused on categories such as vigilance, technological advances, and protection. According to the data analysis the most accurate filled categories (slots) in the article mentioned above contain the following prototype agents (see Figure 1).

Vigilance is the category that includes the following lexical units: people $(0,87 \%)$, surveillance $(0,62 \%)$, government $(0,43 \%)$, video $(0,38 \%)$, camera $(0,24)$.

Technological advances is the second important category to mention that embraces the lexical units such as facial recognition $(0,81 \%)$, system $(0,34 \%)$, industry $(0,29 \%)$, project $(0,24 \%)$, artificial intelligence $(0,19 \%)$.

Protection is represented by means of the words such as police $(0,62 \%)$, security $(0,34 \%)$, report $(0,34 \%)$, crime $(0,34 \%)$. 


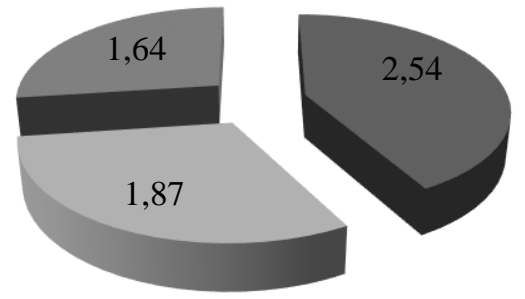

Vigilance

Technological advances

Protection

Figure 1. Frame analysis data of the discourse of the article "Beijing Bets on Facial Recognition in a Big Drive for Total Surveillance".

The second article under analysis "China's New Surveillance State Puts Facebook's Privacy Problems in the Shade" is also taken from the daily American newspaper "The Washington Post" (Pomfret, 2018). Data analysis proves that the discourse of the article is mostly aimed at dealing with two essential categories such as vigilance and confidentiality. The most accurately filled categories (slots) in the article "China's New Surveillance State Puts Facebook's Privacy Problems in the Shade" contain the following prototype representatives (see Figure 2).
The first category regarded as vigilance consists of the following lexical units: technology $(0,77 \%)$, police $(0,66 \%)$, camera $(0,55 \%)$, data $(0,44 \%)$, phones $(0,33 \%)$, facial recognition $(0,33 \%)$, security $(0,33 \%)$, apps $(0,22 \%)$, messages $(0,22 \%)$

Confidentiality as the second category accommodates the following assembly of words: privacy $(0,55 \%)$, data $(0,33 \%)$, efficiency $(0,22 \%)$, safety $(0,11 \%)$.

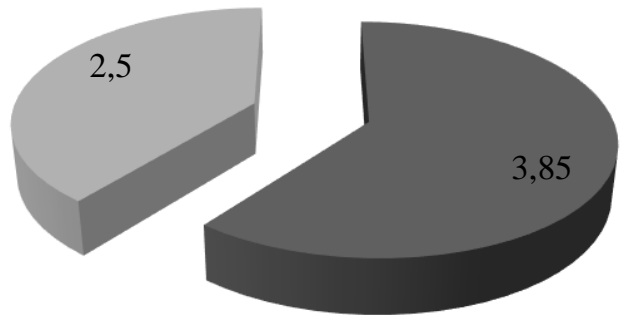

- Vigilance

Confidentiality

Figure 2. Frame analysis data of the discourse of the article "China's New Surveillance State Puts Facebook's Privacy Problems in the Shade".

The article under analysis "Internet Users in China Expect to Be Tracked. Now, they want Privacy" is taken from "The New York Times" (Mozur, 2018). The article concentrates its attention on the tree paramount categories amidst which are social interaction, credit system and personal data (see Figure 3).

The content of the category social interaction is represented by users $(0,74 \%)$, internet $(0,74 \%)$, chat $(0,52 \%)$, online $(0,44 \%)$, surveillance
$(0,3 \%)$, app $(0,3 \%)$, social media $(0,22 \%)$. Credit system as the category includes the set of words such as privacy $(0,74 \%)$, system $(0,52 \%)$, people $(0,3 \%)$, relationship $(0,22 \%)$, behaviour $(0,22 \%)$, finances $(0,22 \%)$, protection $(0,15 \%)$.

Personal data as one more category assembles such words as data $(1,18 \%)$, government $(0,52 \%)$, information $(0,37 \%)$, fraud $(0,22 \%)$, consumers $(0,15)$. 


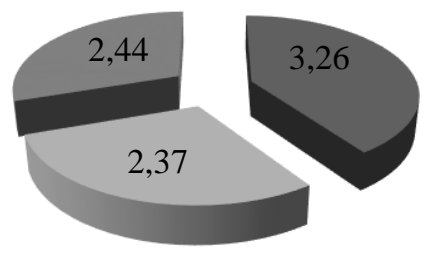

- Social interaction

Credit system

n Personal data

Figure 3. Frame analysis data of the discourse of the article "Internet Users in China Expect to Be Tracked. Now, they want Privacy" is taken from "The New York Times".

The category vigilance is found to be the most sizeable in the article "Beijing Bets on Facial Recognition in a Big Drive for Total Surveillance" (Denyer, 2018). This category is represented via the widely used word surveillance mentioned in the article extremely often which consequently means that surveillance as the notion is of primary importance for the author of the newspaper text mentioned. The author refers to the methods the government uses to track people's actions. He points out that the camera and video surveillance is beneficial for the Chinese. The author also lays the stress on the advantages of the camera and video surveillance as e.g. it makes door opening or restraint payment easier. Although, he does not put forward strong arguments against surveillance technologies, but puts the emphasis on the fact the government is in for achieving the control over people's life.

The category technological advances is also significant as it proves the Chinese government's desire to dominate the global artificial-intelligent industry. It shows that the country pays a lot of attention to tech industry, start-ups and head hunting by graduates from top American universities and former employees of companies like Google and Microsoft.

The category protection demonstrates that the facial recognition technology is used for providing safe environment for citizens. Thus, surveillance is featured as a means to track suspects, spot suspicious behaviour and even predict crime. Moreover, it's an excellent chance for coordinating the work of emergency services, monitoring the comings and goings of people, official documents and security industry reports show.

As the result, all the categories in the article make it possible to mention that Chinese government takes care of its nation. The first dominant category vigilance which seems to sound a bit negative has absolutely positive effects. The surveillance realized via facial recognition and artificial intelligence makes the life of both Chinese people and police better and easier as surveillance technology make it possible to finally achieve the level of control over people's lives that they aspire to. The author grabs the world's attention to the Chinese data technologies focusing on the fact that China has more data than anywhere else in the world, the fact that Chinese is the nation that is purely data driven, the fact that it's easier for them to collect sufficient training data.

In the article "China's New Surveillance State Puts Facebook's Privacy Problems in the Shade" (Pomfret, 2018) the category vigilance is considered to be the most essential and is a good size as well. However, in this article this category is full of different prototype representatives. Thus, the same category is seen with some shade of different meanings. In the article "China's New Surveillance State Puts Facebook's Privacy Problems in the Shade" facial recognition and other tracking technologies are viewed as powerful tools for law enforcement not only to prevent separatism but also to spy on population whereas in the article "Beijing Bets on Facial Recognition in a Big Drive for Total Surveillance" facial recognition is presented as a way to care about the population and to protect in dangerous and risky situations.

The category confidentiality is a bit narrower. In terms of this article, privacy issue is not a great concern for Chinese. As an example taken from the article there is a situation with Mao Yan who violated the traffic regulations. She apologized pointing out there was no fencing to block jaywalkers like her but the officers were intent on prosecution. When Mao Yan said she had not memorized her ID number, one officer snapped her picture with a camera phone. Within some seconds he read out her name, her ID card number and date of birth. The girl was taken 
aback by the police experience and quite scared not having personal privacy.

In the article "Internet Users in China Expect to Be Tracked. Now, they want Privacy" (Mozur, 2018) the broadest category is called social interaction. The author refers to the various types of internet activity as a way to track people's actions. Consequently, social networks, different apps, and chats play a great role in the constant surveillance. Moreover, the author points out that the users themselves reveal personal data that later may be used by the third parties.

The category credit system is of less importance. As Beijing is going to introduce a new social credit system, the authorities claim to give and take away privileges based on spending habits, online and real-world behaviour, and social relationships. Thus, the slots relationship, behaviour, finances, protection are of great importance. The author believes that soon foreign travel, speedy internet, school access and social benefits could be granted or denied based on a person's score. One of the ways to check and track a person's score is to collect data by different internet companies. That's why the author has some concerns about privacy and personal data protection of Chinese citizens.

The last category to analyse is personal data. The author puts the significant accent on leaking of the personal information which is a great matter of consequence amidst consumers. The author is also concerned about an increasing number of internet fraud cases and personal data sale via online marketplaces. Besides, he mentions that people neglect their own internet security as they usually agree to the terms of service without thoughtful reading; thus the agree to the hidden terms that's a right to give a private information to the third parties.

\section{Conclusions}

Comparing the articles from the "Washington Post" and "The New York Times" some common features of outlining the topic surveillance are noticed. All the articles bring surveillance into the sharp focus as a complex and controversial issue. Although the titles of the articles differ a bit, the frames and their slots are alike. The authors show a great concern about the internet security and privacy but at the same time seem to be careful with criticizing new tracking systems. Along the arisen alert concerning surveillance, the authors prove the facial recognition technology and artificial intelligence can provide people with the save environment free of risky and extremely dangerous situations, free of crime and separatism. However, they admit that such technology is more likely to be used to keep a closer watch on citizens.

\section{Bibliographic references}

Allen, M. (2017). Frame analysis. The SAGE Encyclopedia of communication research methods,

https://dx.doi.org/10.4135/9781483381411.n210

Berger, A. A. (2019). Media and communication research methods: An introduction to qualitative and quantitative approaches (5th ed.). SAGE Publications, Inc.

Cacciatore, M., Scheufele, D. \& Iyengar, S. (2016). The End of Framing as We Know It ... and the Future of Media Effects. Mass Communication and Society, 19(1), 7-23. http://doi.org/10.1080/15205436.2015.1068811

Denyer, S. (2018). Beijing bets on facial recognition in a big drive for totals. The Washington Post. Retrieved 15 May, 2019 from https://www.washingtonpost.com/news/world/w p/2018/01/07/feature/in-china-facial-

recognition-is-sharp-end-of-a-drive-for-totalsurveillance/?noredirect=on\&utm_term $=$. a $29 \mathrm{fc} 2$ c22790

Diachuk, N. V. (2016). To the problems of literary texts research in psycholinguistics. The problems of philology and translation are topical, $10(1)$, 241-245. http://nbuv.gov.ua/UJRN/apftp_2016_10\%281 $\% 29 \_51$

Diachuk, N. (2017). Frame analysis of political texts. East European Journal of Psycholinguistics, 4(1), 40-46.

Dijk, van T. A. (2008). Discourse and context: A sociocognitive approach. Cambridge University Press.

Dijk, van T. A. (2011). Discourse studies: A multidisciplinary introduction (2nd ed.). SAGE Publications, Inc. http://dx.doi.org/10.4135/9781446289068

Dobrosklonskaja, T. G. (2008). Medialinguistics: A systematic approach to learning the language of the media (Modern English media speech). Moskva, Russia: Flinta, Nauka.

http://www.ffl.msu.ru/research/publications/dob rosklonskaya/dobrosklonskaya-

medialingvistika.pdf

Fillmore, C. J., \& Baker, C. F. (2012). A frames approach to semantic analysis. In B. Heine \& H. Narrog (Eds.), The Oxford handbook of linguistic analysis. Oxford University Press. DOI:

https://doi.org/10.1093/oxfordhb/978019954400 4.013.0013 


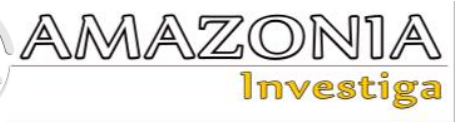

Gorp, Van B. (2007). The construction approach to framing: Bringing culture back in. Journal of Communication, 57(1), 60-78. DOI: https://doi.org/10.1111/j.0021-

9916.2007.00329.x

Hansen, A. \& Machin, D. (2019). Media and communication research methods (2nd ed). Red Globe Press, Pages: 323

Kahneman, D. (2013). Thinking, fast and slow. Nueva York: Farrar, Straus and Giroux.

Knusden, E. (2014). Media effects as a two-sided field: Comparing theories and research of framing and agenda setting, edited by Kramp, Leif, Carpentier, Nico, Hepp, Andreas, Trivundža, Ilija Tomanić, 207-16. Bremen, Germany: Edition Lumière. 207-217. Retrieved from

http://www.researchingcommunication.eu/SUS Obook201314.pdf

Kuypers, J. A. (2010). Framing analysis from a Rhetorical perspective. New York: Routeledge, 286-311.

Leeper, T. J. \& Slothuus R. (2019). How the news media persuades: framing effects and beyond. In E. Suhay, B. Grofman \& A. H. Trechsel (Eds.). The Oxford handbook of electoral persuasion. DOI: https://doi.org/10.1093/oxfordhb/978019086080 6.013.4

Mozur, P. (2018). Internet users in China expect to be tacked. Now, they want privacy. The New York Times. Retrieved 15 May, 2019 from https://www.nytimes.com/2018/01/04/business/ china-alibaba-privacy.html.

Nikonova, Zh. (2008). The main stages of the frame analysis of speech acts (based on the material of modern German). Bulletin of the Nizhny Novgorod University. N.I. Lobachevsky, No 6, 224-228.

Pomfret, J. (2018). China's new surveillance state puts Facebook's privacy problems in the shade. The Washington Post. Retrieved 15 May,
2019 from https://www.washingtonpost.com/news/globalopinions/wp/2018/03/27/china-newsurveillance-state-puts-facebooks-privacyproblems-in-the-

shade/?noredirect=on\&tum_term=.ba77d $2 \mathrm{e} 80 \mathrm{c} 1$ 2.

Scheufele, D., \& Tewksbury, D. (2007). Framing, Agenda Setting, and Priming: The Evolution of Three Media Effects Models. Journal of Communication 57(1), 9-20. doi: 10.1111/j.0021-9916.2007.00326.x

Schiffrin, D., Tannen, D. \& Hamilton H. E. (2015). Introduction to the first edition. In D. Tannen, H. E. Hamilton \& D. Schiffrin (Eds.), John Wiley \& Sons, Inc. (pp. 1-7). https://doi.org/10.1002/9781118584194.ch0

Sonnet, J. (2019). Priming and framing: dimensions of communication and cognition. In W. H. Brechus \& G. Ignatow (Eds.), The Oxford handbook of cognitive sociology. DOI: 10.1093/oxfordhb/9780190273385.013.13

Stoughton, J. (2017). A framing analysis of news discourse in the case of environmental racism in Lincolnville. Nova Scotia: Dalhousie University Halifax.

Zasiekina, L. (2007). Language and culture impact on individual intelligence. In: Challenging Tasks for Psycholinguistics in the New Century. J. Arabski, Ed. Katowice: University of Silesia. P. 256-262. (in English) ISBN 978-83-60743-07-2

Zasiekina, L. \& Zasiekin, S. (2008). Psycholinguistic diagnostics. Lutsk, Ukraine: Vezha.

Ziem, A. (2014). Frames of understanding in text and discourse: Theoretical foundations and descriptive applications. John Benjamins Publishing https://doi.org/10.1075/hcp.48 